\title{
A PERSONAGEM DINAURA, DE ÓRF ̃̃OS DO ELDORADO: VOZES NARRATIVAS E ALTERIDADE NA CONSTRUÇÃO DO ENIGMA DA FEMINILIDADE ${ }^{1}$
}

\author{
Francisca Andréa Ribeiro da Silva ${ }^{2}$ \\ Sylvia Maria Trusen ${ }^{3}$
}

\begin{abstract}
RESUMO
Este artigo discute o como a personagem Dinaura, pertencente à obra Órfãos do Eldorado, de Milton Hatoum, é construída pela voz narrativa e pelas perspectivas dos personagens que, com ela, participam do enredo. Dessa forma, observa-se as relações de alteridade e a influências dessas relações na constituição dessa personagem. Além disso, nota-se como Dinaura e as outras órfãs ambientadas nesta novela relacionam-se com alteridades étnica e religiosa, nas negociações culturais, linguísticas e de crenças, não deixando de retratar as consequências da colonização no período moderno, como o processo de tradução cultural presente nessas relações, as quais são de sujeitos pós-coloniais. Assim, para tanto, apoia-se nas concepções de Fanon (1968; 2008), Burke (2009), Beauvoir (2016) e Genette (1989), entre outros.
\end{abstract}

Palavras-chave: Personagem enigmática. Perspectiva narrativa. Tradução. Alteridade.

\begin{abstract}
This article discusses how the character Dinaura, belonging to Milton Hatoum's Órfão do Eldorado, is constructed by the narrative voice and by the perspectives of the characters who, with her, participate in the plot. Thus, the relations of alterity and the influence of these relations on the constitution of this character are observed. In addition, it is noted how Dinaura and the other orphans set in this novel relate to ethnic and religious alterities in cultural, linguistic and belief negotiations, while portraying the consequences of colonization in the modern period, such as the translation process cultural relations present in these relations, which are of postcolonial subjects. Thus, it is based on the conceptions of Fanon (1968, 2008), Burke (2009), Beauvoir (2016) and Genette (1989), among others.
\end{abstract}

Keywords: Enigmatic character. Narrative perspective. Translation. Otherness.

\section{INTRODUÇÃO}

Órfãos do Eldorado é a quarta obra do escritor Milton Hatoum e assim como os demais textos ficcionais deste autor, esta obra tem conquistado leitores de diferentes países, traduzida em outras línguas, além de ter conquistado o Prêmio Jabuti e elogios da crítica literária, sendo também adaptada para o cinema. O enredo retrata a história de Arminto

\footnotetext{
${ }^{1}$ Este estudo compõe parte da dissertação de mestrado intitulada Cinzas do Norte e Órfãos do Eldorado, de Milton Hatoum: vozes narrativas e alteridade na construção das personagens femininas, defendida em junho de 2017 pelo programa de pós-graduação em Linguagens e Saberes na Amazônia. Trabalho de autoria de Francisca Andréa Ribeiro da Silva, sob orientação da profa. Dra. Sylvia Maria Trusen

${ }^{2}$ Mestre em Linguagens e Saberes na Amazônia - Universidade Federal do Pará. Endereço eletrônico: andrearibsilva@hotmail.com

${ }^{3}$ Doutora em Letras e Profa. da Universidade Federal do Pará, vinculada aos programas de pós-graduação, Linguagens e Saberes na Amazônia e Estudos Antrópicos da Amazônia. Pesquisadora da RELER - Catedra Unesco de Leitura PUC/Rio. Pós-doutoramento pela Universidade Federal do Rio de Janeiro, no Programa de Pós-Graduação Ciência da Literatura. Orientadora. Endereço eletrônico: sylviatrusen@me.com
} 
Cordovil, narrador homodiegético ${ }^{4}$ que na velhice rememora sua vida, contando-a a um viajante. Dessa maneira o leitor passa a conhecê-la. Em linguagem enxuta e envolvente, Arminto conta de si e das outras personagens que tiveram contato com ele. Dentre elas, o narrador dá destaque à personagem Dinaura, uma órfã por quem ele se apaixona e se envolve perdidamente, passando a viver em função de reencontrá-la, pois Dinaura desaparece misteriosamente. Muitos segredos, dentre eles o envolvimento dela com Amando, o pai de Arminto, ajudam a compô-la, que é construída a partir de lacunas, lendas e lembranças.

A investigação aqui consiste em perceber como Arminto, assumindo uma perspectiva de um ser amante, desenha a personagem Dinaura ao destacar a personalidade e as demais características da moça e de que forma ela se torna a memória insistente dele, ao ponto do narrador apagar outros objetivos de sua vida e vislumbrar o reencontro com Dinaura como principal meta.

Aspectos que dizem respeito às relações de alteridade são igualmente observados nesse estudo, no intuito de anotar como Dinaura é vislumbrada na sua condição de órfã, do Sagrado Coração de Jesus, atentando aos possíveis desrespeitos à sua condição étnica e religiosa. Para compreender este aspecto, a concepção de alteridade discutida por Fanon (1968; 2008) irá contribuir, uma vez que esse teórico aborda as consequências da colonização para as populações de países outrora colonizados. Assim, o entendimento de como Dinaura se constitui perpassa pela compreensão da condição de Arminto, neto de um dos colonizadores na região amazônica, como é destacado na obra e se verá adiante. Dessa forma, é necessário discutir, ainda que de maneira sucinta, as consequências da colonização no período moderno, tempo em que se situa a obra, para se conjecturar o porquê da orfandade de meninas tapuias.

Então, cabe adentrar no universo ficcional de Órfãos do Eldorado, atentando às palavras usadas pelo narrador para buscar compreender a construção dessa enigmática personagem.

\section{A ENIGMÁTICA DINAURA}

Dinaura, juntamente com Arminto, constitui-se como personagem principal, pela relevância que ganha no enredo e na vida de Arminto, um narrador autodiegético, o qual

\footnotetext{
${ }^{4}$ Terminologia cunhada do teórico Genette (1989), a qual se refere ao narrador que participa do enredo. Vale mencionar que essa categoria homodiegética é considerada por Genette em duas situações: o narrador que participa da história, mas não é o centro dela, posicionando-se perifericamente e contando o que observa, chamado de observador testemunha e aquele que conta sua própria história, o narrador autodiegético, caso de Arminto.
} 
detém uma visão limitada sobre o que o rodeia e, principalmente, em relação à Dinaura, como se verá adiante. Pelo fato dele ser apaixonado por ela, o mesmo demonstra uma perspectiva de um ser amante, que a engrandece, que não descreve simplesmente a personagem, mas relata sobre a mulher a quem está encantado e isso vem influenciar na maneira de narrar.

Abaixo, observa-se a primeira impressão que o narrador teve de Dinaura:

[...] Uma delas tinha jeito de moça crescida. Parecia uma mulher de duas idades. Usava um vestido branco e olhava para o alto, como se não estivesse ali, como se não estivesse em lugar nenhum. De repente o olhar me encontrou e o rosto anguloso sorriu. Eu não conhecia a moça. Olhei tanto que a diretora do colégio do Carmo se aproximou de mim. Madre Joana Caminal veio sozinha, me deu os pêsames e disse secamente: O senhor Amando Cordovil era o homem mais generoso desta cidade. Vamos rezar por sua alma. E foi embora, a moça e as outras órfãs atrás dela (HATOUM, 2008, p. 28).

Neste trecho, percebe-se o contato do narrador com a personagem, até então desconhecida por ele. Isso é denotado com o uso do artigo "uma", que remete ao sentido de indefinição. Essa ideia também recai sobre a idade exata da moça, pois ele demonstra ignorar a idade da jovem, o que é percebido por meio das conjecturas que realiza, ao usar as expressões "moça crescida" e "duas idades", as quais aludem à ideia de uma moça alta, com certa maturidade, mas não determinam com precisão. Ele enfatiza, também, a expressão do olhar dela, o qual subentende que a personagem está com um pensamento longe daquele espaço. Outro aspecto destacado por ele é a geometria do rosto da moça, em que se nota, a partir da palavra anguloso, um rosto de formato pontiagudo. Outrossim, observa-se que nesse trecho o narrador a apresenta como uma das órfãs do orfanato e que as órfãs eram conduzidas por uma madre, sendo tal aspecto notado pela expressão "atrás dela", declarando, assim, a hierarquia que se atribui à madre e a submissão das órfãs em relação à religiosa.

Quanto ao olhar da personagem, o narrador afirma: "O olhar de Dinaura era o que mais me atraía. Às vezes um olhar tem a força do desejo. Depois o desejo cresce, quer penetrar na carne da pessoa amada [...]" (HATOUM, 2008, p. 31). Assim, ele demonstra o poder de atração e a força do olhar da moça para conduzi-lo ao desejo. De um olhar que o estimula à excitação carnal. Abaixo, vislumbra-se um trecho da obra, no qual Arminto deixa transparecer seu encantamento por Dinaura:

Dinaura deixou o livro na areia e entrou sozinha na água. Nadou e deu um mergulho tão demorado que senti falta de ar. Quando ela apareceu nua, com o vestido enrolado no pescoço, senti o corpo tremer de desejo. Tenho certeza de que me viu, porque as meninas apontavam para mim, riam e davam beliscões na bunda e nas coxas de Dinaura. De longe, fiquei lambendo aquele corpo na luz do fim da tarde. Nem lembrei da Escada dos Pescadores: desci correndo o barranco, e, quando me 
aproximei do rio, Dinaura já estava vestida e andava à frente das meninas. Segui o vestido molhado até a rampa da Ribanceira, atalhei por uma escada de barro e lá em cima parei diante de Dinaura. Disse que queria conversar com ela. Vi os olhos de espanto no rosto fora do mundo, o sorriso nos lábios grandes e molhados; ainda toquei nos ombros dela, antes de vê-la correr para a praça do Sagrado Coração (HATOUM, 2008, p. 34).

Acima, percebe-se as reações do narrador, que se confessa envolvido pelo corpo, ousadia e sensualidade de Dinaura. A naturalidade com que ela trata a nudez faz lembrar outra personagem da obra do romancista, Cinzas do Norte. A órfã, assim como Algisa, despe-se sem nenhum pudor. Quanto à metáfora, "lambendo aquele corpo", compreende-se expressar o desejo que Dinaura causava em Arminto. O uso do verbo lamber, no sentido figurado, substitui a expressão "olhando aquele corpo", no entanto, não se trata de um simples olhar, mas uma visão desejosa, que envolve. Outrossim, a sinestesia, por misturar sensações demonstra, dessa forma, que o narrador saboreia o que vê. E em relação à expressão "andava à frente", sugere-se que o narrador não apenas evidencia a posição espacial em que andava a moça, como denota que dentre elas, Dinaura é quem as conduzia, significando também o destaque que o narrador imprime à mesma, em relação às demais. Já com a frase "rosto fora do mundo", traz à Dinaura uma peculiaridade de uma mulher que se faz outra, não pertencente ao mundo em que vivia ou à situação em que se encontrava, ou, como mais tarde se verá, uma personagem lendária. Ainda, nessa citação, observa-se que o corpo molhado corrobora para a construção da sensualidade feminina. Já a presença do livro, nesta cena, certifica que Dinaura tinha o hábito da leitura, como é perceptível, a seguir, pela visão de Estiliano: “[...] eu mandava livros, porque ela gostava de ler [...]” (HATOUM, 2008, p. 98).

Outras características da personagem podem ser percebidas por sua vestimenta: “[...] usava um vestido de chitão florido [...]" (HATOUM, 2008, p. 34). Tendo em vista que o tecido chita é de pouco valor, uma fazenda de algodão barata e rala, atribui-se, então, por extensão, a precária condição financeira da moça. Além do mais, sugere-se que esse tecido caracteriza a simplicidade de Dinaura. Outro trecho que reforça essa ideia é: “[...] meu pai tinha razão, eu era um aproveitador de índias e pobretonas [...]" (HATOUM, 2008, p. 42). Assim, a perspectiva do narrador, em relação a ela, dá-se pela concordância deste com a opinião do pai, que a considera como índia pobre, opinião acentuada pelo advérbio de intensidade "muito", reforçando o grau de pobreza da moça. Além do mais, atesta, assim, seu ponto de vista quanto à origem dela, apesar de ser apenas uma conjectura, pois ela constitui-se como enigmática, envolta em mistério: “[...] uma índia? Procurei a origem, nunca encontrei [...]" (HATOUM, 2008, p. 15). Pela visão limitada do narrador, ela não é revelada por inteiro, 
sendo configurada, dessa forma, como enigma insondável, fazendo com que o outro deseje compreendê-la.

O fato do narrador construí-la como uma mulher que não se expressa: “[...] Eu me acostumei com o silêncio, com a voz que eu só ouvia nos sonhos" (HATOUM, 2008, p. 41), acentua ainda mais o mistério em torno dela, pois Dinaura se obscurece na sua mudez e com isso, os discursos sobre ela são vários e a maneira como é vista difere entre os enunciadores, os quais elaboram conjecturas no intuito de entendê-la, mas a compreensão total não se completa:

No porto de Vila Bela, alguém espalhou que a órfã era uma cobra sucuri que ia me devorar e depois me arrastar para uma cidade no fundo do rio. E que eu devia quebrar o encanto antes de ser transformado numa criatura diabólica. Como Dinaura não falava com ninguém, surgiram rumores de que as pessoas caladas eram enfeitiçadas por Jurupari, deus do Mal (HATOUM, 2008, p. 34-35).

Dessa maneira, o seu silenciamento e o mistério sobre sua identidade corroboram para constituí-la como lendária, com conotação negativa, visto que, como cobra, Dinaura o prejudicaria, levando-o para o fundo do rio. Já em relação aos demais rumores, seria ela possuída pelo diabo, visto que Jurupari, entre os missionários católicos do século XVI, era identificado como o diabo, também visto como uma entidade sobrenatural evocado nos ritos indígenas, presidindo rituais de iniciação masculina. Com isso, as diferentes vozes relegam a ela uma identidade sobrenatural, considerando o mutismo uma consequência do feitiço. Em outra passagem, notam-se mais explicações acerca de Dinaura, também contribuindo para configurá-la como lendária. Diziam que ela estava em uma cidade encantada:

Dinaura foi atraída por um ser encantado, diziam. Era cativa de um desses bichos terríveis que atraem mulheres para o fundo das águas. E descreviam o lugar onde ela morava: uma cidade que brilhava de tanto ouro e luz, com ruas e praças bonitas. A Cidade Encantada era uma lenda antiga, a mesma que eu tinha escutado na infância. Surgia na mente de quase todo mundo, como se a felicidade e a justiça estivessem escondidas num lugar encantado (HATOUM, 2008, p. 64).

Vale lembrar que o enredo de Órfãos do Eldorado, narrado por analepse ${ }^{5}$, percorre a sorte trágica do narrador-personagem, concentrando igualmente elementos diversos que vão da lenda da fundação de Manoa - o lugar confundido pelos colonizadores com Eldorado - à glória da Manaus - sob o influxo da borracha e seu posterior declínio. Assim, Dinaura é

\footnotetext{
${ }^{5}$ Como se viu na primeira parte deste trabalho, o enredo não linear de Órfãos do Eldorado se dá com idas ao passado, por meio das memórias de Arminto.
} 
caracterizada sob conjecturas, como elemento dessas lendas. A seguir, observa-se uma referência à lenda do Eldorado:

\begin{abstract}
Uma das lendas mais persistentes e que mais incendiou a imaginação dos conquistadores foi a do El Dorado. País fabuloso situado em algum lugar do noroeste amazônico, dele se dizia ser tão rico e cheio de tesouros que, segundo a lenda, o chefe da tribo recebia em todo o corpo uma camada de ouro em pó e a seguir se banhava num lago vulcânico. [...] em busca do El Dorado também foram para as selvas outros europeus, como portugueses, franceses, holandeses e irlandeses. [...] os conquistadores, homens pertinazes em seus ódios e amores, jamais renunciaram às suas mais íntimas ilusões, que lhes serviram de estímulo e consolo. E todos quiseram se apossar da riqueza escondida, desses países fabulosos que foram progressivamente mudando de nome e de lugar: Guyana, El Dorado, Candire, Paititi, Mojos, Manoa, mantendo sempre as mesmas promessas e causando os mesmos desenganos [...] (SOUZA, 2009, p. 69-70).
\end{abstract}

À vista disso, a personagem Dinaura, a partir dessa referência, seria uma moradora de um país encantado, símbolo de uma promessa de riquezas ${ }^{6}$.

Vale salientar que o mistério em torno dela não se dá apenas em relação à sua identidade, mas também no que diz respeito à sua relação com Amando:

[...] teu pai quis conversar comigo na Chácara do bairro dos Ingleses. Ele estava nervoso, angustiado. Quase não reconheci o homem. Disse que sustentava uma moça órfã. Por pura caridade. Depois disse que não era só caridade. E me pediu que não contasse para ninguém. Não me disse se era filha ou amante... tinha idade para ser as duas coisas. No começo pensei que fosse filha dele, depois mudei de ideia. E sempre fiquei na dúvida. Foi a única vez que teu pai me confundiu e me magoou. Ele trouxe a moça para cá, disse para madre Caminal que era uma afilhada dele e que devia morar com as carmelitas. Pediu que a diretora guardasse esse segredo. Sei que Dinaura morava sozinha numa casa de madeira que Amando construiu atrás da igreja. Vivia com regalias [...] (HATOUM, 2008, p. 97-98).

Pela voz de Estiliano, passa-se a conhecer as circunstâncias em que Dinaura veio morar no orfanato Sagrado Coração de Jesus. O que chama a atenção é a interrogação persistente: seria ela amante ou filha de Amando? A dúvida sobre isso é um elemento que contribui para constitui-la como enigmática, já que não é do conhecimento do narrador a resposta a esse questionamento, mostrando, dessa forma, que sua visão limitada coopera para que o segredo não se revele. Supõe-se que Dinaura se emudece por medo de não corresponder ao que aspirava o desejo de Arminto, evitando contrariá-lo, pois se infere que falar equivale a falhar, na concepção da personagem, posto que qualquer das duas possibilidades de resposta seria para Arminto decepcionante. Nota-se, ainda, nessa citação, que a órfã possuía um

\footnotetext{
${ }^{6}$ A informação sobre a lenda do Eldorado é importante também para se entender o sentido do título da obra Órfãos do Eldorado, o qual remete às consequências de fatos históricos, como, por exemplo, as órfãs do Sagrado Coração de Jesus e também em relação aos personagens cegos por conta na extração da borracha, a qual é referencialidade em tal ficção: "[...] Trouxe dos seringais do Madeira mais de cem homens, quase todos cegos pela defumação do látex. Lá onde ficava a Aldeia, o prefeito mandou derrubar a floresta para construir barracos. E um novo bairro surgiu: Cegos do Paraíso. [...]" (HATOUM, 2008, p. 95).
} 
tratamento diferenciado no orfanato, em relação às outras, haja vista sua relação com Amando. Sustentada por este, morava sozinha em uma casa atrás da igreja e recebia assistência: de comidas a livros. Só depois de muitos anos é que Arminto ficou sabendo disso, inclusive da origem da moça: tinha nascido em uma ilha do rio $\mathrm{Negro}^{7}$.

Outro aspecto a ser observado é o como descreve o narrador a seguinte cena, em que, em uma única vez, ambos mantiveram relação sexual:

\begin{abstract}
Parecia que estávamos sozinhos na cidade e no mundo. Ela deitou na terra molhada, o pano do vestido colado na pele morena; se despiu sem pressa, a anágua, o corpete e o sutiã, ficou de pé, nua, e tirou minha roupa e me lambeu e chupou com gana; depois rolamos na terra até a mureta da Ribanceira, e voltamos para perto da árvore, amando como dois famintos. Não sei quanto tempo ficamos ali, acasalados, sentindo a quentura nas entranhas da carne. Mal pude ver a beleza do corpo, abismado com o jeito dela, de amar (HATOUM, 2008, p. 51).
\end{abstract}

Nesse fragmento, observa-se a sensação do narrador em relação a esse momento, em que a impressão de estarem sozinhos remete a um momento íntimo e intenso, que só pertencia a ambos e ninguém os atrapalhariam. A maneira como o narrador a descreve ao se despir, sem pressas, e a perda da noção do tempo, por parte do narrador, contribuem para reforçar tal ideia. Além do mais, a sensualidade da personagem é construída pela imagem do tecido colado na pele e os outros elementos da vestimenta dela, como o corpete e a anágua, que estão de acordo com a maneira das mulheres se vestirem nos séculos passados. Assim, a vestimenta se apresenta coerente com o tempo da narrativa. Repare-se, ainda, ser ela uma mulher que se mostra experiente, ou que, pelo menos, não se esconde por trás de uma figura cândida, mas, sobretudo, uma mulher ousada que, nesse momento, sabe o que deseja e sacia os seus ímpetos.

Com a expressão "lambeu e chupou com gana", é perceptível a intensidade do apetite sexual da moça e, ao revelar que se tratavam de "dois famintos", o narrador expõe que ambos estavam ávidos pela comunhão carnal. Todo esse comportamento de Dinaura, em que se mostra sensual e erótica, despertou assombro e espanto no parceiro, tendo em vista o significado do adjetivo “abismado". Desse modo, a personagem é constituída como uma mulher surpreendente, por ter permitido se entregar ao outro com ímpeto.

Entretanto, esse foi um momento único, nos outros ela entra no jogo da entrega e da fuga:

\footnotetext{
${ }^{7}$ Depois o leitor fica sabendo que ela era sustentada pelo pai de Arminto. Era uma órfã, do Sagrado Coração de Jesus, mas que tinha regalias, morava só em uma casa atrás da igreja e recebia toda a assistência de Amando, de comidas a livros. Só depois de muitos anos é que Arminto ficou sabendo disso, inclusive da origem da moça: tinha nascido em uma ilha do rio Negro.
} 
Quando as cinco badaladas me despertaram, o rosto de Dinaura surgiu contra o sol. Não tive tempo de perguntar sobre a dança, nem para me erguer: vi os olhos pretos, grandes e assustados. Podia ser um sonho? Mas eu não queria sonho, desejava a mulher ali, sem ilusões. Então acariciei com os dedos a boca de Dinaura, senti a respiração inquieta, o tremor e o suor nos lábios abertos que roçavam meu rosto. No prazer do beijo, senti uma dentada feroz. Soltei um grito, mais de susto que de dor. Tentei falar, minha língua sangrava. Na confusão, Dinaura escapou (HATOUM, 2008, p. 47).

Essa cena mostra a incerteza de Arminto quanto a ter experimentado, vivido ou sonhado. O fato é que ela é situada entre presença e ausência, já que na maior parte do tempo, ausente fisicamente, mas presente nos sonhos, local onde Arminto dá espaço ao desejo, ao gozo. Além do mais, o beijo, a dentada e a fuga reforçam tal paradoxo. A impressão que ele tem dela, nesse trecho, é de uma pessoa angustiada, percebida pelo olhar em assombro, a inquietação e o tremor, o que se sugere ser em decorrência da possível proibição do amor entre ambos. Talvez por esse sentimento, Dinaura ora é desenhada sorridente, ora triste, mas para ele "[...] triste, ela era mais bonita [...]" (HATOUM, 2008, p. 41). Em alguns momentos se aproximava com ímpeto, em outros, esquivava-se. Esses aspectos paradoxais contribuem para a complexidade da personagem, conduzindo a interpretá-la como uma personagem esférica, já que segundo Candido (2007, p. 63) essa categoria é considerada como tal porque possui como característica a complexidade e a capacidade de surpreender o leitor, ou seja, personagens complexas trazem consigo a imprevisibilidade. E assim se comporta Dinaura.

Seja qual for o comportamento dela, efetivamente a personagem Dinaura possui um efeito grande na vida do narrador, pois é capaz de despertar nele sentimentos diversos: suscitava risada, que "[...] era puro desejo" (HATOUM, 2008, p. 33); surpresa por ações ambíguas, como se observa no parágrafo acima; dúvidas e questionamentos: “[...] queria entender por que ela escondia o passado, por que a dança, o beijo oferecido, a dentada feroz [...]” (HATOUM, 2008, p. 48); saudades, esperanças e desassossego: “[...] Nenhuma palavra, nenhum som, essa mudez crescia e parecia uma faca que me ameaçava, cortando meu sossego [...]" (HATOUM, 2008, p. 92).

Vale salientar que não apenas com Arminto ela despertou sensações: “[...] os homens iam atrás. Nenhum falava com a mulher. Por quê? Medo. Alguma coisa no seu olhar inibia mais que uma voz ou um gesto. Com medo, eram machos vencidos [...]” (HATOUM, 2008, p. 37). Assim, evidencia-se que o olhar de Dinaura possui o poder de inibir o outro e dessa forma, nessa relação de alteridade ela não se revela o outro, de que fala Beauvoir (2016), mulher vista e constituída como menor em relação ao homem. Dinaura revela, antes, o poder de não ser reprimida pela alteridade masculina. 
Com Arminto, ela é o feminino permanente na memória, o próprio pensamento dele: “A verdade é que Dinaura enchia meu pensamento [...]” (HATOUM, 2008, p. 37). Construída como idealização da mulher, acaba não sendo a perfeição esperada, já que, metaforicamente, ela o imobiliza e o conduz para o caminho do desejo, da clausura da esperança, por isso ela se faz tão presente no pensamento e nos sonhos repletos de desejo do narrador. Assim, ao se fazer sempre presente na memória dele, ela contribui na constituição da identidade do mesmo, tendo em vista o que argumenta Candau (2016, p. 99) ao dizer que a memória se constitui de lembranças "[...] que compõem a identidade narrativa do sujeito e asseguram a estrutura dessa identidade”. Portanto, a personagem sendo descrita como memória permanente, ela possui um papel muito significativo na constituição de Arminto.

Vale destacar, outrossim, que ela também é definida por discursos vários, como já se anunciou anteriormente. Os discursos de Florita e Estiliano contribuem, também, para compor Dinaura, pois, algumas características dela só são possíveis de serem percebidas porque o narrador recebe contribuições desses dois personagens, os quais, em suas falas, trazem perspectivas outras sobre ela. Tais vozes surgem através de diálogos mantidos com o narrador, mas que não ganham autonomia narrativa. Entretanto, têm sua importância por revelar, nessas conversas, informações não conhecidas pelo narrador, como alguns aspectos da personagem.

Assim, enquanto outra perspectiva, Florita manifesta sua visão sobre a moça: “[...] E Florita, sem conhecer a órfã, disse que o olhar dela era só feitiço: parecia uma dessas loucas que sonham em viver no fundo do rio" (HATOUM, 2008, p. 31). Florita envolve Dinaura de um poder sobrenatural, mágico, de fascinação, de atração, de encantamento. Além disso, considera-a meio bicho e meio mulher: "[...] Cansou de ser metade bicho metade mulher" (HATOUM, 2008, p. 64), o que vem contribuir para o caráter lendário atribuído à personagem. Estiliano, por sua vez, é o guardião do segredo, é quem confessa a ligação de Dinaura a Amando, quem tem uma visão mais racional da moça, enxergando nela a capacidade de tirar a razão de Arminto: “[...] Estiliano tinha razão: eu estava embriagado por Dinaura; [...]" (HATOUM, 2008, p. 48).

Enquanto representação da mulher ambientada no contexto amazônico, Dinaura e as outras órfãs, do Sagrado Coração de Jesus, são a representação de tapuias assinaladas pela pobreza e pela discriminação: “[...] Vi as filhas de famílias ricas separadas das órfãs, e uma roda de meninas tapuias encolhidas pela timidez e pobreza [...]" (HATOUM, 2008, p. 43). Nota-se a segregação, marcada pelo vocábulo "separação" e apoiada na oposição entre 
meninas ricas e pobres. Observa-se, ainda, pela palavra "encolhidas", a ideia de que as índias estavam se sentindo diminuídas em comparação às outras meninas.

A partir disso, é possível pensar sobre a situação das órfãs e conjecturar as razões para tal condição. Assim, supor que elas sofrem as consequências de ações civilizatórias, sendo a orfandade, dentre outros motivos, resultantes da ação do outro branco sobre a comunidade indígena. Na obra, essa outridade é representada pelo personagem Edílio Cordovil - da classe proprietária de origem lusitana -, rememorado pelo narrador:

[...] Sei que Amando e meu avô tinham inimigos. Amando contava atos heroicos de Edílio: a coragem com que ele e seis soldados derrotaram mais de trezentos revoltosos na batalha do Uaicurapá. Mas outras vozes desmentiam esse heroísmo, diziam que em 1839 Edílio havia comandado um massacre contra índios e caboclos desarmados. Depois dessa matança, ele tomou posse de uma área imensa na margem direita do Uaicurapá. Um sobrevivente deve ter gravado os crimes do tenentecoronel Edílio Cordovil no tronco de uma árvore secular. Amando queria escrever um livro, "Façanhas de um civilizador", uma elegia ao pai dele, um dos líderes da contrarrevolta [...] (HATOUM, 2008, p. 71).

Com essa passagem, sugere-se que as órfãs sofrem as consequências das batalhas travadas entre "civilizador" e indígenas, as quais conduziram à morte destes. Tal aspecto é discutido por Fanon $(1968 ; 2008)$ ao tratar das relações de alteridade entre sujeitos póscoloniais, observando que "[...] é o colono que fez e continua a fazer o colonizado [...]" (FANON, 1968, p. 26). Com efeito, os problemas do período da colonização persistem ainda como consequências de ações de desrespeito e violência ao outro, em que povos de países outrora colonizados, enfrentam sérios problemas sociais e financeiros. E isso é observado na ficção de Hatoum, em que se pode notar personagens indígenas vivendo na cidade em condições financeiras precárias e em contato com personagens de cultura diversa, estabelecendo assim negociações culturais, o que se pode sugerir que são aspectos experimentados por força da colonização e das posteriores imigrações. Em Órfãos do Eldorado, as órfãs vivem sob tais circunstâncias, decorrentes das ações civilizatórias de Edílio Cordovil, avô de Arminto.

Nota-se, no trecho do texto acima, que, na visão de Amando, Edílio era um herói, por ter derrotado os revoltosos, designação esta usada por Amando ao se referir aos índios. Porém, para outras pessoas que representam a visão do narrador, não havia heroísmo na ação de Edílio, mas um criminoso por ter assassinado índios e caboclos, numa luta por conquistas de terras. Esse fato representa bem o que ocorreu no Brasil em relação à figura do colonizador, que passou a dominar inúmeros territórios indígenas. $\mathrm{O}$ desejo de poder e acúmulo de capital trouxe dizimação de muitas etnias. Os sobreviventes, dentre eles as órfãs, 
passaram a morar nas cidades sob condições adversas, como a pobreza e maus tratos. Em Órfãos do Eldorado, há a representação desses índios, por meio de termos como tapuio/tapuia e órfão/órfã. Homens e mulheres indígenas que passaram a morar na cidade, sofrendo as consequências dessas ações. Logo, alude-se ser Dinaura vítima das ações cometidas por pessoas que não vislumbram o outro em sua alteridade, havendo, por conseguinte, o desrespeito às culturas.

Quanto ao motivo de Dinaura residir em um orfanato pode ser explicado por meio de dois caminhos sugeridos pela novela: ela seria filha de Amando, sendo assim, fruto de um relacionamento entre uma mulher amazônica e um homem de origem estrangeira, enquanto representação da formação de uma sociedade híbrida ou a própria amante de Amando, numa relação ilícita para a sociedade da época. Por isso, Dinaura estaria disfarçada entre as órfãs do orfanato. Como o texto de Hatoum é construído por lacunas e a perspectiva é cedida por narrador autodiegético, o leitor permanece ignorando o percurso certo traçado por essa moça, o que confere e intensifica seu caráter enigmático.

Abaixo, observa-se o trecho em que Florita discorre sobre as órfãs do orfanato Sagrado Coração de Jesus, por falar delas, menciona-se também Dinaura, a qual é retratada sob as mesmas condições. Elas são a representação do que ocorria com as jovens índias que perdiam os pais e eram acolhidas pelas freiras em orfanatos, as quais eram conduzidas a adotarem uma língua e culturas, de forma impositiva. Assim são mostradas as órfãs do Sagrado Coração de Jesus:

Florita me disse que várias órfãs falavam a língua geral; estudavam o português e
eram proibidas de conversar em língua indígena. Vinham de aldeias e povoados dos
rios Andirá e Mamuru, do paraná do Ramos, e de outros lugares do Médio
Amazonas. Só uma tinha vindo de muito longe, lá do Alto Rio Negro. Duas delas,
de Nhamundá, haviam sido raptadas por regatões e depois vendidas a comerciantes
de Manaus e gente graúda do governo. Foram conduzidas ao orfanato por ordem de
um juiz, amigo da diretora. Em Vila Bela, madre Joana Caminal era conhecida como
a Juíza de Deus, porque proibia o escambo de crianças e mulheres por mercadorias,
e denunciava os homens que espancavam a esposa e as empregadas (HATOUM,
2008, p. 41-42).

Acima, por meio do discurso indireto, o narrador conta o que ouviu de Florita, a qual detalha a condição de comunicação das órfãs. Envoltas em três línguas: a língua materna - que é a língua indígena de sua aldeia (em estado de proibição) -, a língua geral, ou nheengatu, imposta por uma política de catequização dos jesuítas e depois proibida em favor do uso do português, como fortalecimento da colonização portuguesa. Compreende-se, com os estudos de Rodrigues (2010), a relação dessas línguas com os objetivos da Igreja e dos colonizadores, o que facilita a compreensão desse trecho. Assim, sugere-se que, como representação, as órfãs 
são constituídas de forma a possibilitar ao leitor pensar esses aspectos históricos e se questionar: como fica a identidade dessas personagens, levando em consideração que sua língua materna está silenciada? Como expressar sua cultura e seus saberes, se não podem usar a língua materna? Levando em consideração que seus saberes e culturas são traduzidos em outras línguas, até que ponto essa tradução consegue representar sua cultura? São questionamentos que conduzem a refletir, em articulação com a noção de tradução cultural de Burke (2009, p. 15), o qual relata que toda tradução reside em negociação, envolvendo perdas e renúncias, visto que nenhuma tradução pode ser entendida como uma transposição fiel. Se é assim, isto é, se “[...] quanto maior a distância entre as línguas e as culturas envolvidas, mais claramente aparecem os problemas de tradução [...]” (BURKE, 2009, p. 17), pode-se depreender da leitura do romance, que suas personagens não logram expressar suas culturas plenamente. Tendo em vista que a distância entre a língua portuguesa e as línguas indígenas ${ }^{8}$ é marcadamente diferenciada, em virtude de serem as línguas, entre outros aspectos, de origens culturais distintas, pode-se afirmar que a problemática da tradução é acentuada. A partir disso, pensa-se a condição linguística e cultural dessas órfãs.

Não se pode, ademais, deixar de mencionar que o nhengatu é o resultado já de um processo de tradução: das línguas indígenas vernáculas para a língua geral amazônica, criada, o que não ocorreu sem prejuízos para as comunidades falantes. Dessa forma, conjectura-se que as órfãs são construídas como duplamente prejudicadas, pois tiveram, também, que realizar a tradução do nhengatu para o português.

No contato com outras línguas, são mundos novos que são apresentados às órfãs, que passam por um processo de perdas e de implantação de elementos oriundos de outras culturas à sua, revelando, assim, uma identidade híbrida, formada a partir desses contatos. A imposição da língua portuguesa como língua oficial prejudica a propagação e a vivência de saberes e culturas trazidos por essas órfãs ao novo ambiente em que se encontram.

Outro aspecto a ser mencionado, é quanto à agressão sofrida pelas órfãs, ao serem levadas a abandonarem suas crenças e adotarem a crença das freiras. Silenciadas, elas eram obrigadas a uma rotina que condizia com os preceitos católicos, excluindo, assim, de suas práticas diárias seus valores religiosos. Observar-se-á isso no seguinte trecho:

No fim da tarde, depois das aulas, iam até à capela para dar graças e rezar com as carmelitas. Soube também que faziam um retiro semanal. Cada órfã ficava sozinha

\footnotetext{
${ }^{8}$ Refere-se à língua, nesse período, levando em consideração os primeiros contatos, porque foi o período de em que a língua portuguesa ainda não tinha sido influenciada com termos indígenas. Sabe-se que a língua portuguesa falada no Brasil é resultado dos contatos entre os povos.
} 
num quarto escuro, rezando o rosário inteiro diante do Coração de Jesus iluminado pela chama de uma vela (HATOUM, 2008, p. 41).

A rotina dessas personagens, portanto, é marcada pelo desrespeito às suas crenças, como alteridade religiosa, aspecto que igualmente atinge Dinaura. Passavam a ter contato com culturas impostas, sem o direito de manter seus preceitos vivos, como se observa nesta passagem, sobre um dos hábitos da personagem: "Quando o sino das seis da tarde tocava, Dinaura se ajoelhava para a igreja, os olhos fechados e as mãos no peito [...]" (HATOUM, 2008, p. 42). Sem voz, Dinaura e as outras órfãs são construídas pelo outro. Nesse aspecto, essa alteridade é representada pelas freiras, que as constituem e as educam para acatar a cultura religiosa cristã, ocultando as crenças das mesmas.

É bom ressaltar que, no século XIX e XX, eram consideradas órfãs não só crianças e jovens que tiveram seus pais mortos, mas também, todas as crianças de pais não casados perante a lei:

[...] a justiça muitas vezes foi cega aos direitos de mulheres e crianças índias e mestiças, permitindo que brancos regatões e mesmo altos funcionários públicos fossem agraciados com mulheres e crianças, raptadas, presas ou doadas (no caso das crianças), continuando a prática exercida no Império pelos próprios juízes de órfãos, em virtude de um erro na lei que considerava órfã, toda criança gerada por um casal não casado legalmente, demonstrando assim o legislador um grande desconhecimento da realidade social da região (COSTA, 2005, p. 66).

Na obra de Hatoum não são especificadas as particularidades semânticas do termo órfão, se se trata também dessa vertente interpretativa ou só se refere ao sentido primeiro do termo. O fato é que essa informação histórica faz refletir se eram essas as condições que se encontravam as órfãs das obras de Hatoum. O que chama atenção é que as órfãs presentes na ficção hatouniana são construções de meninas e mulheres, na condição de sujeitos póscoloniais, que tiveram seus direitos tolhidos, tornadas submissas, à mercê do outro: governo e Igreja. Assim, o narrador articula a linguagem de forma a mostrar a personagem Dinaura sendo desrespeitada pelas alteridades étnicas e religiosas.

Apesar do narrador permitir tais reflexões sobre Dinaura, ele não consegue abarcar a totalidade dessa personagem que não se diz toda. Por isso, autoriza outros olhares sobre ela. E, dessa maneira, o leitor é mais uma voz que, na cadeia significante, contribui para a construção de Dinaura. Ela fascina o leitor e o seduz, a ponto de se transformar em memória insistente deste, fazendo-o refletir sobre a desmistificação da representação da mulher na literatura, pois Dinaura é uma construção singular, constituída de palavras, gestos, silêncios, sonhos, devaneios e saudades. Feita de memórias, ela deixa de ser concreta para ser espectro, lembranças e vazio. 


\section{CONSIDERAÇÕES FINAIS}

Um dos aspectos que se fez importante na compreensão da personagem Dinaura diz respeito à perspectiva narrativa, pois observar que Arminto assume a posição de um narrador apaixonado pela personagem a qual descreve possibilitou entender porque ele a engrandece e porque ela se constitui como enigma, pois a visão limitada dele permite muitas lacunas e questionamentos sobre ela. Pode-se perceber que falas de outros personagens sobre Dinaura preenchem alguns espaços vazios permitidos pelo narrador, mas que não capazes de compor a totalidade dessa mulher. Então, notou-se o papel das alteridades na constituição, revelando perspectivas diferenciadas.

Pode-se observar, outrossim, que há, além dessa relação de alteridade - do narrador com a coisa narrada -, a relação entre personagens de origens diferentes, no contexto póscolonial, contribuindo para as traduções culturais e linguísticas e as negociações culturais e religiosas, as quais não ocorrem sem perdas para uma das partes, como se notou na condição das órfãs do Sagrado Coração de Jesus.

Não se pode deixar de mencionar o papel das lendas na constituição da personagem Dinaura, pois as narrativas lendárias proferidas por alguns personagens do enredo concorreram tanto para sua compreensão quanto para corroborar o caráter enigmático da personagem. Dessa forma, a personagem Dinaura, ao se esconder em sua mudez, é enigma desejado pelo outro, que a constrói sob lendas, vazios e lembranças.

\section{REFERÊNCIAS}

BEAUVOIR, Simone de. O segundo sexo: a experiência vivida. Tradução de Sérgio Milliet. 3. ed. Rio de Janeiro: Nova Fronteira, 2016. v. 2.

O segundo sexo: fatos e Mitos. Tradução Sérgio Milliet. 3. ed. Rio de Janeiro: Nova Fronteira, 2016. v. 1.

BURKER, Peter. Culturas da tradução nos primórdios da Europa Moderna. In: BURKER, Peter; HSIA, R. Po-chia (Orgs.). A tradução cultural nos primórdios da Europa Moderna. Tradução de Roger Maioli dos Santos - São Paulo: Editora UNESP, 2009, p. 13-46.

Hibridismo cultural. Tradução de Sandra Chaparro Martínez. Madri: Akal, 2010.

CANDAU, Joël. Memória e identidade. Tradução de Maria Leticia Ferreira. São Paulo: Contexto, 2016.

COSTA, Heloisa Lara Campos da. As mulheres e o poder na Amazônia. Manaus: EDUA, 2005. 
FANON, Frantz. Os condenados da terra. Tradução de José Laurênio de Melo. Rio de Janeiro: Civilização Brasileira, 1968.

Pele negra, máscaras brancas. Trad. Renato da Silveira. Salvador: EDUFBA, 2008.

GENETTE, Gerárd. Figuras III. Tradução de Carlos Manzano. Barcelona: Editorial Lumen, 1989.

HATOUM, Milton. Órfãos do Eldorado. São Paulo: Companhia das Letras, 2008.

SOUZA, Márcio. História da Amazônia. Manaus: Editora Valer, 2009. 